\title{
Simulated scenes: a pedagogical experiment to reflect about conflict management in nursing care
}

\author{
Cenas simuladas: uma experimentação pedagógica para pensar o gerenciamento de \\ conflitos nos cuidados de enfermagem \\ Escenas simuladas: una experimentación pedagógica para pensar la administración \\ de conflictos en los cuidados de enfermería
}

'Universidade Federal de Roraima. Boa Vista, Roraima, Brazil.

How to cite this article:

Silva PS. Simulated scenes: a pedagogical experiment to reflect about conflict management in nursing care.

Rev Bras Enferm. 2020;73(Suppl 5):e20200025 doi: http://dx.doi.org/ 10.1590/0034-7167-2020-0025

\section{Corresponding author:} Paulo Sérgio da Silva E-mail: pssilva2008@gmail.com

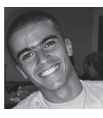

EDITOR IN CHIEF: Antonio José de Almeida Filho ASSOCIATE EDITOR: Ana Fátima Fernandes

Submission: $01-13-2020$

Approval: 06-01-2020

\section{ABSTRACT}

Objective: To describe simulated scenes on conflict management in nursing care, created by university students; and to identify the skills and attitudes needed by the nursing student to manage conflicts in health care. Methods: This is a qualitative study conducted with 28 university nursing students from a public college located in the city of Boa Vista, Roraima. The strategy adopted for the production of data was the simulation of scenes of conflict. The data were analyzed according to Bardin's methodology. Results: Four conflict scenes were produced, involving nurses and nursing technicians, health managers, multiprofessional health teams, and patient care. In this context, 274 record units were identified regarding skills and attitudes for nurses to manage conflicts. Final considerations: The skills and attitudes essential for conflict management were: effective verbal communication, body language observation, knowing how to listen, negotiate, make decisions, be neutral, impartial, and how to lead democratically.

Descriptors: Simulation Technique; Education Nursing; Conflict of Interest; Health Services Administration; Nursing Care.

\section{RESUMO}

Objetivo: Descrever cenas simuladas sobre gestão de conflitos no cuidado de enfermagem criadas por estudantes universitários; e identificar as competências e atitudes necessárias ao estudante de Enfermagem para gerenciar conflitos no cuidado em saúde. Métodos: Estudo qualitativo realizado com 28 estudantes universitários de Enfermagem matriculados em uma instituição pública de ensino superior localizada no município de Boa Vista, Roraima. A estratégia adotada para produção dos dados foi a simulação de cenas de conflitos. Os dados brutos foram analisados segundo Bardin. Resultados: Produziram-se quatro cenas de conflitos, envolvendo enfermeiro e técnicos de enfermagem, gestor de saúde, equipe multiprofissional de saúde e o paciente cuidado. Ao todo, foram identificadas 274 unidades de registros que versam sobre competências e atitudes para o enfermeiro gerenciar conflitos. Considerações finais: Foram identificadas as competências e atitudes indispensáveis para gestão conflitos: comunicação verbal efetiva, observação corporal, saber escutar, negociar, tomar decisões, ser neutro, imparcial e liderar democraticamente.

Descritores: Simulação; Educação em Enfermagem; Conflito de Interesses; Administração de Serviços de Saúde; Cuidados de Enfermagem.

\section{RESUMEN}

Objetivo: Describir escenas simuladas sobre gestión de conflictos en el cuidado de enfermería creadas por estudiantes universitarios; e identificar las competencias y actitudes necesarias al estudiante de Enfermería para administrar conflictos en el cuidado en salud. Métodos: Estudio cualitativo realizado con 28 estudiantes universitarios de Enfermería matriculados en una institución pública de enseñanza superiora localizada en el municipio de Boa Vista, Roraima. La estrategia adoptada para producción de los datos ha sido la simulación de escenas de conflictos. Los datos brutos han sido analizados según Bardin. Resultados: Se produjeron cuatro escenas de conflictos, envolviendo enfermero y técnicos de enfermería, gestor de salud, equipo multiprofesional de salud y el paciente cuidado. En total, han sido identificadas 274 unidades de registros que versan sobre competencias y actitudes para el enfermero administrar conflictos. Consideraciones finales: Han sido identificadas las competencias y actitudes indispensables para gestión conflictos: comunicación verbal efectiva, observación corporal, saber escuchar, negociar, tomar decisiones, ser neutro, imparcial y liderar democráticamente.

Descriptores: Simulación; Educación en Enfermería; Conflicto de Interés; Administración de Servicios de Salud; Cuidados de Enfermería. 


\section{INTRODUCTION}

Every day, teachers and students gather in different spaces to reflect on nursing and its stance in the postmodern world. From this perspective, it is not uncommon to observe nursing students accustomed to the educational experience of just sitting and listening to the teacher talk about topics of interest, while inside the classroom they are induced to learn care management based on traditional teaching-learning strategies ${ }^{(1)}$.

Breaking with this vertical model presupposes the reformulation of the reality of teaching and the learning process of managing care. This prompt students and teachers to take risks collectively in pedagogical paths capable of stimulating creativity, integrating knowledge and reflection beyond themselves, intensifying emotions, freeing one's thinking to act in situations close to the real reality of health work $^{(2-4)}$.

There is a discussion about the imagining of situations of care and the production of simulated scenes ${ }^{(5)}$, which invariably put students in the role of nurse conflict managers. These are challenges that, if overcome, can transform the classroom into the place of professional experiences, where the contents related to conflict management in nursing care gain expression and theorization.

In this context, nursing scene simulation brings students and teachers closer to real contexts and enables the learning of content based on the experiences of those involved. Its main objective is to instigate everyone's reflection through the expressiveness of actions, acts, and knowledge that break with the inherited idea that only scientific rationality should be valued ${ }^{(5-6)}$.

Thus, it is believed that the simulation of conflicts in nursing care, as well as the forms of management expressed by students within simulated scenes, enable the production of scientific knowledge. When using them in nursing education, students and teachers bring fictitious situations closer to reality, identify conflicts, and develop personal and collective skills and attitudes to solve problems ${ }^{(7)}$.

It is a true encouragement to freedom, capable of reformulating thought to reflect the relationships established in education, a provocation that uses learning to identify a conflict, planning the best proposal to deal with the situation, negotiating the decision with the peers involved and evaluating its impacts on the interpersonal relationships of everyone involved in the care scenes.

With these concepts, an opportunity emerges to investigate "conflict management" as a subject of study, from the perspective of university nursing students. Certainly, the scientific experimentation of pedagogies for the liberation of the body, represented by the simulation of scenes, makes it possible to state that, to resolve conflicts, there is no pre-established recipe or formula.

This is because conflicts take place in specific characteristics of human interactions and gain new characteristics according to the context in which they are produced. Thus, they are permeated by the social interaction present in the services and conditioned by the work process of the organization. Therefore, it is not the general and subjective human relationships that are in conflict, but those shaped by the concreteness of the interactions during life ${ }^{(8)}$.

Understanding this, it is pertinent to pay attention to the reconfiguration of nursing education, in order to guarantee support for the development of specific professional skills and attitudes that characterize the practice of conflict management in nurses. This requires contemplating the plurality of skills to be developed in daily practice, which need a collective effort in the search for theoretical and practical tools, offered during graduation to support future nurses in their practice ${ }^{(9)}$.

Usual, but not frequent, the simulated scenes can reshape the training of nurses, especially when, as apprentices, they are invited to manage conflicts in simulated health facilities. It is believed that the simulations of conflicting scenes, in addition to being significant, are indicative of the expression of thought, encouraging skills and attitudes, especially when the simulated scenes portray situations that can change the teaching of the problem-theme (conflict management) in the curricula of Nursing courses.

From this preliminary contextualization, the following guiding question for this investigation emerges: What are the simulated scenes that nursing students can create about the role of nurses in conflict management? What are the skills and attitudes present in the simulations that are capable of inducing reflection on conflict management in nursing care?

\section{OBJECTIVES}

To describe simulated scenes about conflict management in nursing care, created by university students; and to identify the skills and attitudes needed by nursing students to manage conflicts in health care.

\section{METHODS}

\section{Ethical aspects}

The research followed the guidelines from Resolution 466/2012 of the National Health Council. The study project was submitted to the Research Ethics Committee (CEP) and approved. All data produced was preceded by a reading and signing of the Informed Consent Form. It should be noted that the anonymity of the participants in this investigation was maintained.

\section{Type of study}

This is an exploratory, descriptive study with a qualitative approach. This type of investigation makes it possible for the researcher to answer more specific questions. It considers the truth of the experience being lived, collectively oriented towards what is plausible and practical. Qualitative studies work as a recipe stored since childhood that is used over the years, representing habits, behaviors, and actions ${ }^{(10)}$.

Selecting this type of study stands out for its vitality in the health field. This is because they provide detailed analyses of human experiences, helping researchers to acquire more in depth information about a phenomenon of interest ${ }^{(11)}$. It should be noted that this research met all the consolidated criteria for qualitative research reports listed in the COREQ instrument.

\section{Methodological procedures}

First, the proposal to create "simulated scenes about conflict management in nursing care" was included in the schedule of 
pedagogical activities in the module "Organization of health services", presented to the participants in the first meeting with the class and without evaluative models.

Then, the theme, the objectives, relevance, stages of the dynamics and form of data production were explained to the participants. After agreeing to participate in the investigation, a date, time, and place for carrying out the investigation was scheduled. In all, four simulations were carried out with an average duration of nine minutes each. In them, situations were discussed that dealt specifically with the skills and attitudes essential to nurses to manage conflicts within the scenes care.

\section{Study setting}

The study was carried out in Boa Vista, capital of the state of Roraima, located in the Legal Amazon region. The municipality, located in the extreme north of Brazil, currently has five higher education institutions: two public and three private ones. The context chosen for the study was a graduation Nursing course from a public university, which is justified by the fact that it is the only institution in the state of Roraima that uses, in the training of nurses, a curriculum guided by active teaching-learning methodologies.

\section{Data source}

The social group involved in this investigation was made up of 27 Brazilian students regularly enrolled in the 4th year of the Graduation Nursing course and by a Colombian student in academic mobility at the institution, to a total of 28 participants.

The selection considered the following inclusion criteria: being enrolled in the module "Organization of health services" in the 2nd semester of 2019. Nursing students who refused to participate in the study or to scientifically disseminate the knowledge produced were excluded from the investigation. The social group involved in the study was mainly represented by women with an average age of approximately 22 years.

\section{Collection and organization of data}

The production of data was divided in three moments: idealization of simulations, presentation of simulated scenes, and collective problematization of conflicts present in nursing care.

At the first moment, students were invited to form four groups containing seven participants. The distribution was per affinity, and the researcher who produced the data distributed descriptions to induce the simulations. First group: a conflict between a nurse and a nursing technician; second group, a conflict between a nurse and a health manager; third group, a conflict between nurses and other health professionals; and, finally, fourth group, a conflict arising from the relationship between the nurse and the patient being cared for.

It is important to note that, at this stage, a student was selected by a consensus of the group as the responsible for recording all collective discussions that took place as the simulations were idealized, which lasted an hour and 15 minutes. The producer of the pedagogical experimentation requested authorization from the group to film the simulations. The researcher remained impartial to the doubts raised by the groups.
At the second moment, the students were asked to form a semicircle to present the simulations of the conflict scenes. At this stage, the students responsible handed over the records of each group, and two students were asked to collaborate by filming the simulations, so that the statements could be transcribed later, as a complementary way of producing the data. The order of presentation followed the sequence of groups previously defined.

After the four simulations on conflict management, three students were selected, according to their availability, to produce records complementary to that of the conductors of the experimentation. Thus, clockwise from the semicircle, each student, one by one, was invited to comment on the pedagogical experimentation adopted, as well as on the skills and attitudes necessary for nurses to manage conflicts present in the simulated nursing care routine.

\section{Data analysis}

All the data produced, as a result of the records in the four groups, in the transcription of the contents present in the filming and the four sources of records of the collective problematization, underwent analytical treatment according to the theoretical framework provided by Bardin ${ }^{(12)}$.

The record units (RU) that emerged from the analytical process were organized in the description of four simulated scenes about conflicts in nursing care, and the contents of the pedagogical experimentation were organized in the category entitled "Managerial skills and attitudes expressed by nursing students in simulated conflict scenes".

\section{RESULTS}

In all, 274 RUs were identified, regarding the managerial skills and attitudes necessary for conflict resolution. The content units were organized in two decoding units: "Basic skills identified in the simulated scenes for conflict management" and "Attitudes learned by nursing students for conflict management in nursing care".

In the first decoding unit, communication and observation were found to be fundamental elements for conflict management, represented, respectively, by 112 and $74 \mathrm{RUs}$. As for the attitudes learned by nursing students in conflict management present in the second decoding unit, the analyses showed the following results: knowing how to listen (28 RUs), knowing how to negotiate (15 RUs), being neutral (12 RUs), being calm (9 RUs), being impartial (7 RUs), being patient (5 RUs), making a decision (4 RUs), being a democratic leader (3 RUs), putting yourself in another person's place (2 RUs), preventing conflicts (2 RUs), and self-control of emotions during a conflictive situation in nursing care (1 RU).

It is worth highlighting that four simulations resulted from this pedagogical experimentation, which contain scenes about nurses' skills and attitudes in conflict management. The syntheses of the simulations created by university nursing students can be seen bellow.

\section{Simulation created by group I: Conflict between nurses and nursing technicians in the emergency sector}

The situation in which the conflict is produced emerges from the practical experiences of nursing students in activities of an 
academic league. The scenes produced take place inside the emergency department of a hospital. The management nurse requests that the nursing team be educated regarding the handling of the blood gas equipment which, on a recurring basis, is damaged.

The assistance nurse at the unit, communicates the performance of the activity to her nursing team, composed of three technicians. From these, a nursing technician refuses going, crosses her arms and gets in a conflict with the nurse, claiming that the gasometry is a private activity of the nurse. After an unsuccessful dialogue with the professional, the management nurse who proposed the training is called.

The nurse identifies the conflict, calmly explains to the nursing technicians the objective of the training, which consists in handling and maintaining the gasometer. Once the doubts are resolved, the technicians recognize the need for the activity and agree to participate.

\section{Simulation created by group II: Conflict between a nurse and a manager in the Primary Family Health Unit X}

The situation was intuitively idealized by the nursing students. The simulation was set in a basic health unit and started with a telephone conversation between the municipal health secretary and the service manager. In the phone call, the secretary arbitrarily informs the manager that funds will be cut from the unit due to unnecessary expenses incurred by the service.

The unit manager, in turn, calls a meeting with the health team, attended by two nurses, a nursing technician, and a professional from general services. The manager informs everyone about the cut in funds and proposes a radical reduction in the performance of preventive exams by nurses from ten to two per day.

Nurses do not accept the reduction and engage in a conflict with the manager. In the opportunity, the nursing technician informs that drugs are being taken from the pharmacy. The nurses, knowing the fact, ask the manager to investigate the problem and, after much dialogue and negotiation, reach a meeting point: reduction of two preventives exams, five rapid pregnancy tests and cleaning of the unit once a day, as a way to contain expenses.

\section{Situation created by group III: Conflict between a nurse and a multiprofessional health team in the Intensive Care Unit (ICU)}

The situation in which the conflict is produced emerged from the professional experiences narrated by a professor to nursing students. The patient is a 38 year-old female, victim of a car accident, quadriplegic, hospitalized for about a year in the ICU, with no prognosis for discharge, with great possibility of evolving to death according to medical reports.

In one of the care scenes involving medication administration, the lucid patient asks the nurse on duty to see her son. The assistance nurse assures her that the meeting will take place. Knowing the norms, rules, and routines of the ICU, a team meeting is formed. There are two nurses, two doctors, a physical therapist, and a social worker.

At the meeting, there are clearly divergent opinions. A doctor speaks out against the visit, arguing that the ICU is a restricted area and that the risks of infection for children are high. On the other hand, the other doctor believes it is possible to humanize the high-complexity environment. The social worker says that the rules are made to be broken and that it should be possible to hold this meeting.

At the climax of the conflict, the management nurse, the negotiator of the situation, asks, with a peaceful attitude, for calm in the environment that is agitated, with shouting and discussions. After tempers were dampened due to her attitudes, the solution to the problem was negotiated and they all reached an agreement: the client would be transferred to a sector of the hospital, accompanied by the ICU team, and there would be a meeting between the mother and her son.

\section{Simulations created by group IV: Conflict established between nurses and patients in the maternity}

The situation in which the simulated conflicts were idealized emerged from the daily care experiences of nursing students in a public maternity hospital in the far north of the country, impacted by the migration process.

The first simulation portraits a Brazilian pregnant woman accompanied by her mother. Together, mother and daughter enter the health service reporting pain in the hypogastric region. When going through the nursing consultation, they are asked to wait in the waiting room. Three hours later, a foreign pregnant woman arrives, alone, reporting severe pain in the entire anterior abdominal region; when attended by the nurse, she was immediately referred to the delivery room.

Seeing the situation, the Brazilian pregnant woman engages in a conflict with the nursing professionals. With a high tone of voice, upright, hand on her waist and aggressive posture, she asks for explanations about the reason that led the foreign pregnant woman to "pass ahead of her" in the service, considering that she pays her taxes on time. The unit's nurse is called and tries to identify the elements of the conflict. After obtaining information from the nursing professionals, she explains the phases of labor in a calm and serene way to the pregnant woman and her mother and informs that the case of the immigrant was an emergency. The mother, hearing the explanation, calmed the daughter, and the conflict was resolved.

In the second simulation, now involving the foreign puerperal woman, the nursing technician, when vaccinating her newborn son, is faced with aggression and denial by the mother regarding the procedure. The nurse is called upon to mediate the conflict. When talking to the puerperal woman, she identified a language barrier that made it impossible to understand the objectives and benefits of vaccination. When the limitations of the language were broken, an effective therapeutic communication was carried out, and the procedure could be carried out.

\section{DISCUSSION}

The discussions pointed to the emergence of considerations about fundamental skills and attitudes for students to manage conflict in nursing care. In concrete terms, the escape from what is usually taught takes place when teachers stand side by side with students, to experience simulations of conflicting scenes, which, in their nature, were permeated by ethical issues.

From this perspective, the way to teach and learn conflict management needs to be discussed beyond the projections in 
the classroom. The students indicate that the simulated scenes make it possible to see nursing practice more clearly, as a true mirror of the daily care, a pedagogical experimentation that integrates knowledge and takes everyone out of their comfort zone.

Therefore, it can be said that pedagogical practice in the field of nursing, as the main didactic strategies in use indicates, points to new possibilities to be explored. Among them, the expansion of the use of educational technologies and simulation as an active methodology stands out ${ }^{(13)}$.

Furthermore, in the search for the alignment of the training of nurses with the proposals expressed in the national curricular guidelines, other strategies, such as the simulation of scenes, are likely to be implemented. This activity can offer society a professional who is critical, reflective, humanitarian, open to constant updating, with supported by scientific evidences, who can assume their leading role in the management of nursing care ${ }^{(1,5,14)}$.

Research on nursing administration shows that the skills and attitudes of a manager involve two aspects: organization and teamwork. In terms of organization, it is necessary to consider planning, work processes, physical structure, and people management. Regarding the work team, the awareness of health professionals is considered, as well as their autonomy, social problems, and behaviors ${ }^{(15)}$.

In the theoretical field, it is challenging to establish a guiding framework for discussing the skills and attitudes involved in conflict management. Therefore, the discussions of the findings were based on the administrative theory of human relations, which is focused on people, on the valorization of subjective factors present in the work process, human motivation, leadership, and communication ${ }^{(16-17)}$.

All of these aspects were (in)directly addressed in the simulations; however, when looking at the first record unit, verbal communication supported by effective dialogues and observation of body language within relationships emerged as basic skills for conflict management.

The evidence points out that open communication between health professionals allows for the identification of communication problems. The establishment of effective communication mechanisms and tools reveals possible incidents and conflicts. In this context, it is important for health professionals, especially nurses, to have an effective communication, not only because of the impact on patient safety, but also because of the consequences in the professional and personal lives of workers ${ }^{(18)}$.

Such communication goes beyond what is spoken and is expanded in the messages expressed by the body. With this objective, it is important that nurses train their eyes to effectively see, recognizing that observation, in addition to being a basic care instrument, helps nurses in the management process of conflicts born in scenes of care.

From this perspective, it is necessary for nurses to expand their observation capacity and detect nonverbal evidences of the patient, the nursing team, or even the health team involved in the conflict. This is because gestures determine fluctuations in the use and amplitude of the body senses observed, showing possibilities for decision making in the face of the conflict at stake ${ }^{(19)}$.

In the second record unit, the contents analyzed directed the discussions to the attitudes that nurses need to have when conflict is mediated. In this RU, verbs in the infinitive emerged marking the following actions: to know how to listen, to know how to negotiate, to be neutral, to be impartial, to make decisions, to be a democratic leader, to put oneself in the place of other people, and to prevent conflicts. In addition, they signaled elements of a personal order, and therefore, strictly subjective ones, such as: to be patient, to be calm, and to have self-control over one's emotions in order to manage the conflict.

These attitudes reinforce that care management is a relational, non-linear practice that requires a well-developed repertoire from the nursing student, reaffirming that managerial and caring activities, properly speaking, cannot be practiced separately in the nurse's work process, as they act in an integral and recursive manner ${ }^{(20)}$.

Thus, the integration between managing and caring, as well as the interaction, articulation, decision-making, and cooperation that should guide the human relationships established by the nurse with the members of the multidisciplinary team, are currently presented as an emerging need for the development of a management model linked to care, with the sharing of tasks between all members and qualification and comprehensive care to the user for conflict prevention ${ }^{(17,21)}$.

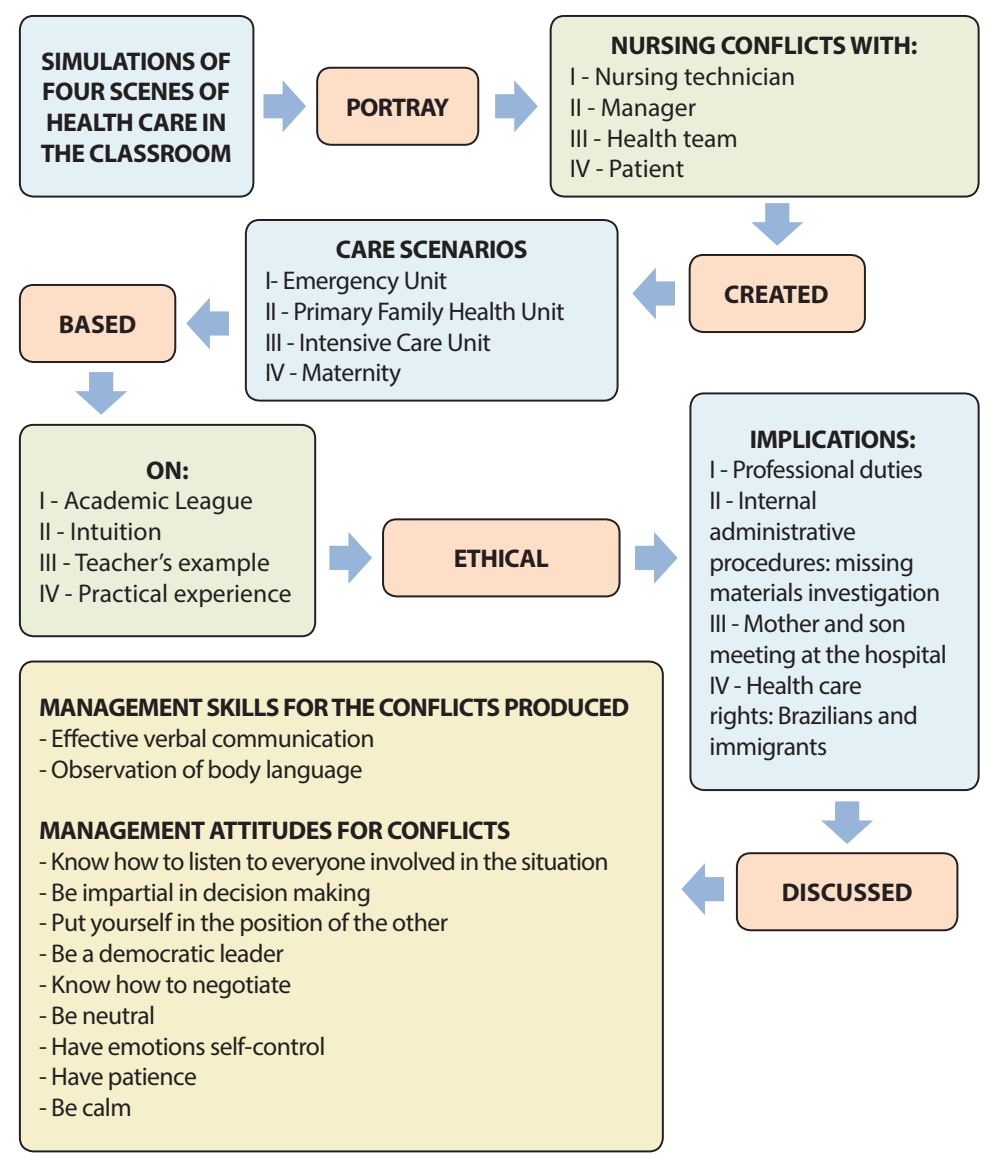

Figure 1 - Synthesis of the skills and attitudes identified in the simulations by nursing students 
Another point to be highlighted in the context of health work concerns the emotional rules of the organization disseminated through discourses shared by the group, which can determine not only the emotions transmitted, but also a sense of purpose that shows direction and intentionality at work. Individuals receptive to this purpose produced by the organization, realizing and accepting the mission of his work, will be able to perform the emotional work more naturally, and can justify to themselves the necessary efforts to manage his emotions ${ }^{(22)}$.

In a conflict situation, it was found that emotional aspects can be intensified or mitigated depending on the organizational context and the people involved ${ }^{(23-24)}$. In this context, the results of this study signal emotions that deserve to be highlighted in the nurse's action in managing conflicts, such as anger, hatred, sadness, fear, complete absence of emotion, disappointment; and these can be marked by visible actions like crying, lowering the head, retracting the body, and excessively increasing the tone of voice. Based on these concepts, the discussions led to the production of a synthetic illustration that show the simulated scenes and their implications for the formation of skills and attitudes in nursing students, which is indispensable for conflict management in care settings.

\section{Study limitations}

Generalizing the results was possible due to the size of the sample involved in the investigation. However, the considerations produced imply the formation of skills and attitudes to be addressed on in higher education nursing courses.

Certainly, this study suggest a review of the social group involved in the research and recognizes that it is essential to carry out the same data production strategies with nursing professionals, as a way to identify new skills and attitudes that benefit the practice of teaching and managing conflicts.

There is a need to access nurses, located in the extreme north region, who face daily managerial challenges of different types, namely: lack of human resources, scarce materials, unhealthy environments, exposure to countless risks, work overload, administrative impositions, dissatisfaction with the management model. Admittedly, we look at these challenges as catalysts for conflicts within the nursing care scenes, which call for new investigations into the operational modes of conflict management assumed by nurses.

\section{Contributions to the field of Nursing, Health, or Public Policy}

The study directly benefits teachers who teach the topic "conflict management" for future nurses. This is because, based on the simulation of care scenes, skills and attitudes were identified to be worked on pedagogically with nursing students.
In addition, the abandonment of rigid and inflexible teachinglearning models in favor of the use of simulation of scenes about conflicts led the students to become interested and attentive, integrating different types of knowledge, bringing them closer to practical settings and, mainly, brought to the center of the discussions the object of nursing action: care.

Thus, the results of this investigation are believed to enable, in the practical field of nursing management teaching, new ways to think about conflict management in the field of health. In addition, it is considered that the skills and attitudes identified serve as situational diagnoses for coordinators of nursing graduation courses to improve pedagogical practices in multivariate spaces for teaching and learning.

\section{FINAL CONSIDERATIONS}

The use of scene simulation as a pedagogical experimentation to think about the teaching of conflict management in nursing care proved to be a pleasant teaching strategy for university students. The simulations created in this investigation demonstrated the potential for the development of skills and attitudes in those involved, in order to manage conflicts in four dimensions: nurses with their team technicians, nurses with health managers, nurses with the multidisciplinary health team, and nurses with the patient.

Based on this, nursing students strengthened their creative potential, integrated knowledge, based on practical and life experiences, and elaborated four scenes of care that were set in the urgency and emergency unit, the $\mathrm{HBU}$, the ICU, and the maternity. All scenes are rife with ethical elements in the field of nursing, which suggests an integration between these curricular components.

From this perspective, the research identified, as elementary skills for the effective management of nursing in conflicts: verbal communication conducted with effective dialogues and observation of the body language of those involved in the conflictual situation. It is a rescue of the basic instruments of care, which were here worked scientifically, in the managerial dimension.

Regarding attitudes, it was observed that nursing students want to know how to listen to everyone involved in the conflict, how to negotiate situations, to be impartial, to make decisions at the right time, to be democratic leaders, to be calm, patient, serene, to have self-control and to put themselves in the position of the others involved in the conflict.

The considerations that end here are expected to develop in the practice of teachers, nursing students, nurses, managers, and health workers, who daily face conflicting situations in the production of health care. Thus, with the certainty that there is still much to be done, it is believed that new investigations involving simulations of care scenes will be developed to validate the effectiveness of this pedagogical experimentation in the field of nursing.

\section{REFERENCES}

1. Araujo STC, Torres DA, Costa EM, Azevedo AL, Silva PS, Figueiredo NMA. Projetando imagem e pensando o corpo nos diferentes espaços. Rev Pesqui: Cuid Fundam. 2018;10(1):68-74. doi: 10.9789/2175-5361.2018.v10i1.68-74 
2. Silva PS, Figueiredo NMA. Corpo do professor: discursos sobre subjetividade para pensar a formação de enfermeiros. Rev Bras Enferm. 2018;71(Suppl 4):1805-9. doi: 10.1590/0034-7167-2017-0456

3. Silva PS, Azevedo AL, Silva CSM, Araujo STC, Machado WCA, Figueiredo NMA. Corpo do professor: reflexões práticas sobre subjetividade e poder na formação de enfermeiros. Enferm Foco. 2019;10(1):117-21. doi: 10.21675/2357-707X.2019.v10.n1

4. Silva PS, Figueiredo NMA. The teacher's body elements that influence the teaching-learning process of university nursing students. Invest Educ Enferm. 2017;35(3):268-75. doi: 10.17533/udea.iee.v35n3a03

5. Costa EM, Silva PS, Silva TASM, Durante ALTC, Figueiredo NMA, Tonini T. Cenas de situações de cuidar e implicações éticas: uma experiência com estudantes de graduação no espaço de ensinar. Rev Enferm UFPE [Internet]. 2015 [cited 2020 Apr 15];9(Suppl7):9000-8. Available from: http://periodicos.ufpe.br/revistas/revistaenfermagem/article/view/10691/11752

6. Jensen S, Kushniruk AW, Nohr C. Clinical simulation: a method for development and evaluation of clinical information systems. J Biomed Inform. 2015;54:65-76. doi: 10.1016/j.jbi.2015.02.002

7. Arveklev SH, Berg L, Wigert H, Morrison-Helme M, Lepp M. Learning about conflict and conflict management through drama in nursing education. J Nurs Educ. 2018;57(4):209-16. doi: 10.3928/01484834-20180322-04

8. Silva IS, Arantes CIS, Fortuna CM. Conflict as a possible catalyst for democratic relations in the work of the Family Health team. Rev EsC Enferm USP. 2019;53:e03455. doi: 10.1590/S1980-220X2018003403455

9. Ferreira VHS, Teixeira VM, Giacomini MA, Alves LR, Gleriano JS, Chaves LDP. Contribuições e desafios do gerenciamento de enfermagem hospitalar: evidências científicas. Rev Gaúcha Enferm. 2019;40:e20180291. doi: 10.1590/1983-1447.2019.20180291

10. Minayo MCS, Costa AP. Fundamentos teóricos das técnicas de pesquisa qualitativa. Rev Lusófona Educ [Internet]. 2018 [cited 2019 Sep 11];40(40):139-53. Available from: http://revistas.ulusofona.pt/index.php/rleducacao/article/view/6439

11. Watkins DC. Rapid and rigorous qualitative data analysis: the "RADaR" technique for applied Research. Int J Qual Methods. 2017;16:1-9. doi: $10.1177 / 1609406917712131$

12. Bardin L. L'analyse de contenu. Paris: Presses Universitaires de France; 2013. 296 p.

13. Santos JLG, Souza CSBN, Tourinho FSV, Sebold LF, Kempfer SS, Linch FC. Estratégias didáticas no processo de ensino-aprendizagem de gestão em enfermagem. Texto Contexto Enferm. 2018;27(2):e1980016. doi: 10.1590/0104-070720180001980016

14. Rigobello JL, Bernardes A, Moura AA, Zanetti ACB, Gabriel CS, Laus AM. Ações assistenciais e gerenciais desenvolvidas no Estágio Curricular Supervisionado: impressão dos atores envolvidos. Rev Esc Enferm USP. 2018;52:e03369. doi: 10.1590/S1980-220X2017035303369

15. Moraes VCO, Spiri WC. Desenvolvimento de um clube de leitura sobre o processo gerencial em enfermagem. Rev Bras Enferm. 2019;72(Suppl 1):230-7. doi: 10.1590/0034-7167-2018-0019

16. Motta FCP. Teoria geral da administração: uma introdução. São Paulo: Pioneiras; 2002.

17. Chiavenato I. Introdução à teoria geral da administração: uma visão abrangente da moderna administração das organizações. Rio de Janeiro: Elsevier; 2003.

18. Moreira FTLS, Callou RCM, Albuquerque GA, Oliveira RM. Estratégias de comunicação efetiva no gerenciamento de comportamentos destrutivos e promoção da segurança do paciente. Rev Gaúcha Enferm. 2019;40(esp):e20180308. doi: 10.1590/1983-1447.2019.20180308

19. Moreira AGM, Azevedo AL, Figueiredo NMA, Oliveira LFD, Araújo STC. Comportamento proxêmico da enfermagem no espaço da hemodiálise. Acta Paul Enferm. 2017;30(4):343-9. doi: 10.1590/1982-0194201700051

20. Montezeli JH, Almeida KP, Haddad MCFL. Nurses' perceptions about social skills in care management from the perspective of complexity. Rev Esc Enferm USP. 2018;52:e03391. doi: 10.1590/S1980-220X2017048103391

21. Mororó DDS, Enders BC, Lira ALBC, Silva CMB, Menezes RMP. Análise conceitual da gestão do cuidado em enfermagem no âmbito hospitalar. Acta Paul Enferm. 2017;30(3):323-32. doi: 10.1590/1982-0194201700043

22. Santos EF, Fontenelle I. A construção de sentido para o trabalho emocional. Rev Adm Mackenzie. 2019;20(1):1-28. doi: 10.1590/1678-6971/ eramg190089

23. Beserra EP, Gubert FA, Martins MC, Vasconcelos VM, Figueiredo GA, Silva La, et al. Gerenciamento de conflitos na formação do enfermeiro. Rev Enferm UFPE [Internet]. 2018 [cited 2020 Apr 17];12(10):2891-6. Available from: https://periodicos.ufpe.br/revistas/revistaenfermagem/ article/view/236080/30280

24. Pereira ER, Silva RMCRA, Silva JO, Oliveira DC, Silva MA. Competência interpessoal como proposta para a gestão de conflitos no trabalho em saúde: revisão integrativa. Rev Enferm UFPE [Internet]. 2013 [cited 2020 Apr 17];7(Esp):4918-27. Available from: https://periodicos.ufpe.br/ revistas/revistaenfermagem/article/view/11751/14030 